\title{
The Future of the Eastern Timber-wolf in the United States
}

For more than three centuries, wolves in the United States have been depicted as noxious, bloodthirsty, and treacherous. No epithet has been thought too base, and no death has been thought too cruel, for what seemed one of the most hostile features of people's environment. Extermination of wolves began with the early colonists, for when they landed in America, wolves inhabited most of the continent. One subspecies, the Eastern Timber-wolf (Canis lupus 'Lycaon'), ranged from Canada in the north to Florida in the south, and westwards into Minnesota. Today, Eastern Timber-wolves, also called Gray Wolves, comprise the only viable populations of wolves in the conterminous United States. (Scattered Red Wolves /Canis rufus] exist in the south, but cross-breeding with Coyotes [Canis latrans] has diluted the species.) The majority of Eastern Timber-wolves remaining-about 1,000 to 1,500 animals-live in northern Minnesota. In addition, a stable-and muchstudied-population inhabits Isle Royale in Lake Superior, and about twenty individuals live in Upper Michigan and a similar number in Wisconsin (Mech, 1966; Peterson, 1977).

\section{Present Status}

The present range of the Eastern Timber-wolf is only about $3 \%$ of what it was originally. Decline of essential habitat, and continued pressure to exterminate wolves, led to the animal being listed as an endangered species in 1974. Eastern Timberwolves are now legally protected as 'threatened' under the Endangered Species Act of 1973. A threatened species is one that may become endangered in the foreseeable future, and will thus be in danger of extinction.

In 1985 the Eighth Circuit Court of Appeals will decide whether control over wolves in Minnesota will be transferred to the State, or retained by the United States Department of the Interior. The Court's decision could be crucial. Minnesota challenges the wolves' status as a threatened species, and has proposed annual sport-kills if the programme of control is transferred to State control. The Department of the Interior, once firmly against a transfer, reversed itself in 1982. An alliance of conservation groups intervened to require the Department to cease acting in contravention of the Endangered Species Act's mandate to conserve endangered and threatened species. The trial court agreed with the conservation groups, but the Department of the Interior appealed the trial court's decision to the Eighth Circuit Court of Appeals.

\section{Past Persecution}

The present litigation continues the age-old conflict between people and wolves in the United States. Pilgrims hated wolves even before they encountered them. Early settlers envisaged themselves as sent to the New World 'as sheep in the midst of wolves' (Matthew, x:16). 'God's plan for the pilgrims' was thought to be the transformation of wilderness into farms and settlements, and this plan was executed remorselessly. As the land was settled, wilderness was destroyed, and White-tailed Deer (Odocoileus virginianus) surrounding the settlements were hunted below critical population-levels. Beaver (Castor canadensis) and other small fur-bearers were trapped yeararound, populations failed to sustain themselves, and consequently crashed.

Wolves adjusted to the decimation of the deer and other prey species by increased attacks on an alternative prey: livestock. Retaliation by the settlers was swift and deadly; bounties were paid, hunts were organized, and traps were devised. Wolves ac- tually preying on livestock became merely one target of a campaign to exterminate wolves from the United States.

The westward push of European civilization increased human conflict with wolves. Although wolves are able to adapt reasonably well to varying environments, they must have a stable food-supply (Bailey et al., 1978). If those animals forming the food-supply (e.g. deer, Moose [Alces alces], and Beaver) have their critical habitat destroyed, wolves must find alternative prey in order to survive. Transformation of wilderness into sheep-and cattle-ranches inevitably led to a high level of livestock predation.

The solution to stricken farmers seemed clear: poison the predators. It became the custom for range-men to put strychnine into any carcass they passed. The probability that other species would also eat the poisoned carrion was ignored in the determination to kill any and all wolves (Young, 1946). Poison was cheap and plentiful; and its effectiveness was unquestioned. After thousands of predators had been killed, farmers concentrated their attack on loners, until even the most intelligent stalwarts succumbed.

The extinction of entire wolf populations removed the dominant wild predator from vast regions of the United States. As the North American biomes fluctuated in the absence of wolves, a smaller (and therefore less visible) predator expanded its range into former wolf habitat: Coyotes appeared to thrive on adversity, livestock predations continued, and the farmers found that they had failed to gain security by their antiwolf policy.

It would be gratifying to state that public attitudes towards wolves have changed, but it would not be accurate. Fairy-tales of the 'big bad wolf', plus terrifying accounts of were-wolves, are more influential than scientific reality. Now few people will ever see a wolf in its natural state. Even summer visitors to Isle Royale-which has one of the highest wolf densities in the world-rarely see the silent creatures hiding in the shadows (Peterson, 1977); for wolves are afraid of people, and hide from them (Mech, 1966). Much of the recent controversy in Minnesota can be traced to pressure from two sectors: hunters and farmers.

\section{The Minnesota Controversy-Hunting}

In the late 1960s, hunters in Minnesota were concerned about a severe decline in deer: the number of deer hunted dropped from a 1968 total of some 103,000 to 68,000 in 1969 . In 1970 the nine-day hunting season was reduced to two days, and in 1971 there was no open season at all. From 1974 to 1977 , hunting was restricted to bucks only. In 1974, in the midst of the hunting restrictions, the Eastern Timber-wolf was given legal protection as an endangered taxon. Hunters naturally felt that the few deer remaining were being reserved for wolves.

By 1977 even expert biologists were compelled to admit that wolves were a cause of the deer decline. Severe winters and the seral change from good deer habitat to mature forest, reduced the ratio of fawns to does; for with fewer does available as prey, wolves killed a higher proportion of fawns. This reduction of the breeding population led in turn to fewer does being produced during the following year (Mech \& Karns, 1977).

Gradually, however, the deer decline reversed as wolves began a subsequent decline. Lack of food caused wolf cubs to starve to death, until hungry packs were forced to hunt outside their territory, and the ensuing intraspecific strife further re-

(Concluded on page 344) 
duced wolf numbers (Mech, 1977). (Despite historical accounts to the contrary, wolf packs do not combine to form large packs. Folk-tales of hundreds of wolves threatening the lives of valiant frontier families were originated by settlers with more vivid imaginations than accurate memories!) Deer living in buffer zones between wolf-pack territories were found to have an unusually high rate of survival (Nelson \& Mech, 1981). In effect, the buffer zones formed reservoirs that served to repopulate the cores of wolf-pack territory (Mech, 1977). Based on observations of wolves and Moose in Isle Royale, scientists now suggest that wolves and other large mammals have a population cycle of about 38 years, and that severe declines followed by increasing populations are normal in Nature (Peterson et al., 1984).

\section{The Minnesota Controversy - Farming}

Opposition from farming interests is partly the result of implementation of a plan to re-establish wolves in their former habitant where practicable. Such re-establishment has proved to be difficult, as wolves are wide-ranging animals which must have extensive areas of wilderness to survive in their natural state, and generally packs of from two to eight animals inhabit territories of about 120 square miles $\left(310 \mathrm{~km}^{2}\right)$. The dominant pair are usually the only wolves in a pack to breed, producing litters that average five animals each spring. As wolf cubs mature, they either remain within the social hierarchy of the pack or they seek new territory (Bailey et al., 1978).

An area with a stable wolf-population tends to expand as lone wolves move out into new territory and form their own packs. The expansion of wolf range is the crux of farmers' protests. The existence of wolves in relatively inaccessible areas of the Superior National Forest and Voyageurs National Park in northeastern Minnesota does not threaten farmers' livelihoods, but wolves expanding their range into areas further south and west do. Although it has been shown that the presence of wolves in northwestern Minnesota affects the majority of farmers there very little, reports of wolf predation continue. Since 1977 , however, only 38 farmers have claimed aid under a state programme designed to compensate farmers for livestock predation by wolves. Out of the 38 farmers claiming aid, three individuals have received half of the total compensation paid (Schimpf, 1984).

It is difficult for officials to dispute claims of livestock predation. Herds and flocks in northwestern Minnesota are left to graze all summer in pasture containing woodlands and forests, and livestock often are not counted between spring and fall. One farmer reported 31 pregnant cows in spring, but only found 5 calves when his herd was counted again in the fall (Fritts \& Mech, 1981). Wolves may have been responsible for some livestock deaths, but it is unlikely that they were the only cause. Apart from animals lost to disease and dogs, Coyotes are abun- dant in the region, and are increasing. Therefore, even if wolves were exterminated, livestock predation would not be eliminated.

Wolves cannot survive in microcosms of wilderness enclosed by settlements. As human population-pressure in northern Minnesota encroaches on the remaining wilderness, wolf range is reduced. Obviously, farmers losing livestock to predation should be allowed to protect their investment; but will this argument ever cease to be valid? As the last surviving United States wolf is sacrificed to facilitate farming in former wilderness, should the farmer still be entitled to protect his investment?

\section{REFERENCES}

Bailey, R., Mech, L.D., Hickling, W.C., Nicotera, R., Rutske, L., LinN, R.M., RAdTKE, R.E. \& Siderits, K. (1978). Eastern Timber Wolf Recovery Plan. Dept. Interior, Washington, DC, USA. Vol. 1, 79 pp., illustr.

FRITTS, S.H. \& MECH, L.D. (1981). Dynamics, Movements, and Feeding Ecology of a Newly Protected Wolf Population in Northwestern Minnesota. Wildlife Monograph No. 80, 79 pp., illustr.

MECH, L.D. (1966). The Wolves of Isle Royale. USDI, Nat. Park Serv. Fauna Ser. 7:xiv + 210 pp., illustr.

$\mathrm{MECH}$, L.D. (1977). Wolf-pack buffer zones and prey reservoirs. Science, 198, pp. 320-1.

MECH, L.D. \& KARNS, P.D. (1977). Role of the Wolf in a Deer Decline in the Superior National Forest. USDA For. Serv. Res. Paper NC-148, 23 pp., illustr.

NELSON, M.E. \& MECH, L.D. (1981). Deer Social Organization and Wolf Predation in Northeastern Minnesota. Wildlife Monograph No. 77, 53 pp., illustr.

PEterson, R.O. (1977). The wolves of Isle Royale-New Developments. Pp. 3-18 in The Behavior and Ecology of Wolves. (Ed. E. KlinghammeR). Garland STPM Press, New York, NY, USA: xvii + 588 pp., illustr.

Peterson, R.O., Page, R.E. \& Dodge, K.M. (1984). Wolves, moose, and the allometry of population cycles. Science, 224, pp. $1350-2$.

SCHIMPF, A. (1984). Conservationists' howls block wolftrapping season. Audubon Action, 2(3), p. 13.

Young, S.P. (1946). The Wolf in North American History. Caxton Printers, Caldwell, Idaho, USA: 149 pp., illustr.

VALERIE M. FOGLEMAN 4403 54th Street

Lubbock

Texas 79414

USA. 